\title{
Efficacy of Sunflower Residues and Herbicides in Controlling Weeds in Transplanted Rice
}

\author{
Shaon Samanta Tanu, Purnendu Biswas, Sultan Ahmed, \& Swadesh Chandra Samanta \\ Department of Agronomy, Patuakhali Science and Technology University, Dumki, Patuakhali, \\ Bangladesh-8602
}

\section{Abstract}

The experiment was conducted at Agronomy Field Laboratory of Patuakhali Science and Technology University, Dumki, Patuakhali, Bangladesh from July 2018 to November 2018 to find out the effect of sunflower residues and herbicides on weed control and yield of T. Aman rice. Weed control methods tested were $\mathrm{T} 1=$ weedy check, $\mathrm{T} 2=$ Weed free check, $\mathrm{T} 3=$ Pendimethalin, $\mathrm{T} 4$ $=$ Pretilachlor, $\mathrm{T} 5=$ Butachlor, $\mathrm{T} 6=$ Pyrazosulfuron ethyl, $\mathrm{T} 7=$ Bensulfuron methyl + Acetachlor, $\mathrm{T} 8=$ Bispyriback sodium, $\mathrm{T} 9=2,4-\mathrm{D}$ amine, $\mathrm{T} 10=\mathrm{MCPA}$, $\mathrm{T} 11=$ Sunflower residues, $\mathrm{T} 12=$ Sunflower residues $+100 \%$ Pyrazosulfuron ethyl, T13 $=$ Sunflower residues $+75 \%$ Pyrazosulfuron ethyl, T14 = Sunflower residues $+50 \%$ Pyrazosulfuron ethyl. The weed spectrum of the experimental field consisted of all the three groups of weeds viz., grasses (15.78\%), sedges (59.02\%) and broad-leaved weeds (25.2\%). The dominants weeds were Cynodon dactylon and Echinochloa crusgalli among grasses; Cyperus difformis, Fimbristylis miliacea and Scirpus supinus among sedges and Jussiaea decurrens among broad-leaved weeds. Hand weeding recorded the highest weed control efficiency (99.05\%) and weedy check recorded the lowest. Among different herbicides applied alone, butachlor had the highest weed control efficiency (87.59\%). Hand weeding produced the highest grain yield (5.14 t ha-1) which was statistically similar to butachlor, pendimethalin, pretilachlor, bensulfuron methyl + acetachlor and sunflower residues + $100 \%$ pyrazosulfuronethyl. Application of sunflower residues along with the reduced rate ( 75 or $50 \%$ ) of pyrazosulfuron ethyl had effective weed control and satisfactory yield comparable to butachlor. The farmers can use this technology as an eco-friendly approach in transplanted Aman rice field.

\section{Article History}

Received 03 June 2020

Accepted 14 June 2020

\section{Keyword}

Sunflower residues,

Herbicides,

weed suppression,

Yield,

Transplanted Aman

rice

\section{Introduction}

Weeds are the greatest yield-limiting pest to rice reduction and their control is labor intensive. Hand weeding and other traditional control methods are time consuming and involve high labour cost. The rice cropsare severely infested with weeds and can reduce the grain yield by $30-40 \%$ for transplanted Aman rice in Bangladesh (Bhuiyan, 2016). Weeds not only cause huge reductions in rice yields but also increase the cost of cultivation, reduce input efficiency, interfere with agricultural operations, impair quality, act as alternate hosts for 
several insect pests, diseases, affect the aesthetic look of the ecosystem as well as native biodiversity, affect human and cattle health (Bhuiyan et al., 2017). Weeds always compete with crop for resources like light, nutrient, space and moisture causingyield loss. Thus, weed is a serious threat for sustaining rice production in Bangladesh and necessitates proper weed management for rice production. Herbicidal weed control methods offer an advantage to save labour and money and hence regarded as cost effective. Chemical weed control is becoming popular in Bangladesh mainly due to scarcity of labour during peak growing season and lower cost.

Due to high labour and huge time requirement for manual weeding, farmers of coastal area, particularly in Kalapara upazila are using other alternative measures like chemical weed control. Phyrazosulfuron ethyl (a new pre-emergence herbicide) is being used successfully for weed control in T.Aus and T. Aman rice in this area. However, the indiscriminate use of herbicides poses serious problems, such as environmental pollution, human health hazards, developing weed resistance, depletion of crop diversity and reduction of crop productivity (Khanh et al, 2005). Singh et al. (2017) reported that continuous and extensive use of herbicides raised concerns for the long-term sustainability of soil fertility.Allelopathy is suggested as a potential safer method for weed control compared to the use of synthetic herbicides. Many researchers demonstrated that use of sunflower residues alone or in combination with lower rates of herbicides into field soil significantly reduced weed population and dry weight over control (Alsaadawi et al., 2011; Saif et al., 2016; Rawat et al., 2017). However, information available on crop residues and herbicides for weed control in transplanted Aman rice is meager under Bangladesh conditions. Therefore, this study was undertaken to investigate the influence of sunflower residues and herbicides on weed suppression and yield of transplanted Aman rice.

\section{Materials and Methods}

The experiment was carried out at the Agronomy Field Laboratory of Patuakhali Science and Technology University (PSTU), Dumki, Patuakhali, Bangladesh in high land during July to November, 2018. The experimental field belongs to the Agro-Ecological Zone13(Ganges Tidal Floodplain). The experimental soil was clay loam in texture having $\mathrm{pH} 6.0$, organic matter $1.38 \%$, total N $0.09 \%$, available P 6.30 ppm, exchangeable K $0.11 \mathrm{me} / 100 \mathrm{~g}$, available S $15.25 \mathrm{ppm}$ and available $\mathrm{Zn} 0.46 \mathrm{ppm}$. There were fourteen weed control treatments which were as follows:

$\mathrm{T}_{1}=$ Weedy check (Unweeded control)

$\mathrm{T}_{2}=$ Weed free check by hand weeding twice (at 20 and 40 DAT)

$\mathrm{T}_{3}=$ Pendimethalin (PE)

$\mathrm{T}_{4}=$ Pretilachlor $(\mathrm{PE})$

$\mathrm{T}_{5}=$ Butachlor $(\mathrm{PE})$

$\mathrm{T}_{6}=$ Pyrazosulfuron ethyl (PE)

$\mathrm{T}_{7}=$ Bensulfuron methyl + Acetachlor (PE)

$\mathrm{T}_{8}=$ Bispyriback sodium ((PE)

$\mathrm{T}_{9}=2$, 4-D amine (PoE)

$\mathrm{T}_{10}=\mathrm{MCPA}(\mathrm{PoE})$

$\mathrm{T}_{11}=$ Sunflower residues $(\mathrm{PE})$

$\mathrm{T}_{12}=$ Sunflower residues $(\mathrm{PE})+100 \%$ Pyrazosulfuron ethyl $(\mathrm{PE})$

$\mathrm{T}_{13}=$ Sunflower residues $(\mathrm{PE})+75 \%$ Pyrazosulfuron ethyl $(\mathrm{PE})$ 
$\mathrm{T}_{14}=$ Sunflower residues $(\mathrm{PE})+50 \%$ Pyrazosulfuron ethyl $(\mathrm{PE})$

* PE= Pre-emergence, PoE= Post-emergence

Pyrazosulfuron ethyl was studied in combination with sunflower residues because many of the farmers of this region use this herbicide for weed control in rice.

The experiment was laid out in a randomized complete block design with three replications. The layout was completed one day before transplanting. The individual plot size

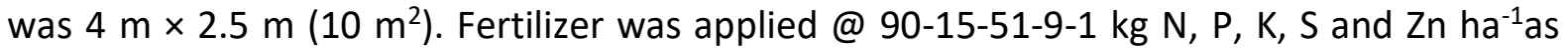
urea, triple super phosphate, muriate of potash, gypsum and zinc sulphate, respectively on soil test basis. Urea was applied in three equal splits; $1^{\text {st }}$ at 15 days after transplanting (DAT), $2^{\text {nd }}$ at 30 DAT and $3^{\text {rd }}$ at 45 DAT. Total amount of triple super phosphate, muriate of potash, gypsum and zinc sulphate was applied during final land preparation. Thirty-two day old seedlings of T. Aman rice variety BRRI dhan49 were transplanted on 9 August 2018 using 2-3 seedlings hill-1 at a spacing of $20 \times 20 \mathrm{~cm}$. The details of the herbicides are given in Table 1 .

Table 1. Details of the herbicides used in the study

\begin{tabular}{|c|c|c|c|c|}
\hline Trade name & Common name & Chemical family & $\begin{array}{c}\text { Rate of } \\
\text { application }\end{array}$ & $\begin{array}{c}\text { Time of } \\
\text { application }\end{array}$ \\
\hline Panida 33EC & Pendimethalin & Dinitroaniline & $2.50 \mathrm{~L} \mathrm{ha}^{-1}$ & 5 DAT \\
\hline $\begin{array}{l}\text { Super Heat } \\
500 \text { EC }\end{array}$ & Pretilachlor & Chloroacetamide & $1.0 \mathrm{~L} \mathrm{ha}^{-1}$ & 7 DAT \\
\hline Amchlor $5 G$ & Butachlor & Chloroacetamide & $25 \mathrm{~kg} \mathrm{ha}^{-1}$ & 5 DAT \\
\hline $\begin{array}{l}\text { Super power } \\
\text { 10WP }\end{array}$ & $\begin{array}{c}\text { Pyrazosulfuron } \\
\text { ethyl }\end{array}$ & Sulfonylurea & $150 \mathrm{~g} \mathrm{ha}^{-1}$ & 7 DAT \\
\hline $\begin{array}{l}\text { Super Mix } 18 \\
\text { WP }\end{array}$ & $\begin{array}{c}\text { Bensulfuran } \\
\text { methyl+ } \\
\text { Acetachlor }\end{array}$ & $\begin{array}{l}\text { Chloroacetamide + } \\
\text { Sulfonylurea }\end{array}$ & $0.74 \mathrm{~kg} \mathrm{ha}^{-1}$ & 7 DAT \\
\hline $\begin{array}{l}\text { Extra power } \\
\text { 20WP }\end{array}$ & Bispyribac sodium & $\begin{array}{c}\text { Pyrimidinylthiob- } \\
\text { enzoates }\end{array}$ & $148 \mathrm{~g} \mathrm{ha}^{-1}$ & 7 DAT \\
\hline Fielder & 2, 4-D Amine & $\begin{array}{c}\text { Phenoxy- } \\
\text { carboxylic acid }\end{array}$ & $2.25 \mathrm{Lha}^{-1}$ & $28 \mathrm{DAT}$ \\
\hline MCPA 500 & MCPA & $\begin{array}{c}\text { Phenoxy- } \\
\text { carboxylic acid }\end{array}$ & $988 \mathrm{ml} \mathrm{ha}^{-1}$ & $28 \mathrm{DAT}$ \\
\hline
\end{tabular}

Liquid or powdery herbicides were applied uniformly with the spray volume of $500 \mathrm{~L}$ $\mathrm{ha}^{-1}$ for pre-emergence spray and $350 \mathrm{~L} \mathrm{ha}^{-1}$ for post-emergence spray using a knapsack sprayer. The pre-emergence application was made uniformly on the soil surface with $5 \mathrm{~cm}$ water depth. Granular herbicide was broadcast uniformly on the soil surface by mixing with dry sand. The weed free treatments were kept weed free up to 40 DAT by hand weeding at 20 and 40 days after transplanting. Weedy plots were allowed season long weed infestation.At physiological maturity, heads of sunflower plants were removed and the plants were harvested, sun-dried for several days and chopped into 2-3 cm pieces. Chopped material was kept under room condition until application. The chopped residues were incorporated into soil 3 days after transplanting of T. Aman rice @ $5 \mathrm{t} \mathrm{ha}^{-1}$. Data on weed density and dry weight wererecorded at 45 DAT randomly from $0.25 \mathrm{~m}^{2}(0.5 \times 0.5 \mathrm{~m})$ area and then converted to per square metre. Dry weight of weeds was taken by drying in an electric oven at $70^{\circ} \mathrm{C}$ until the 
constant weight was recorded. Relative weed density (RWD) in control plots was calculated as follows:

RWD (\%) $=\frac{\text { Density of individual weed species in the community }}{\text { Total density of all weed species in the community }} \times 100$

Weed control efficiency was calculated by using the following formula given by Mani et al. (1973).

WCE $(\%)=\frac{\text { Dry weight of weeds in unweeded control }- \text { dry weight of weed in treatment plot }}{\text { Dry weight of weeds in unweeded control }} \times 100$

An area of $5.12 \mathrm{~m}^{2}(3.2 \mathrm{~m} \times 1.6 \mathrm{~m})$ was harvested from the central portion of each plot to record grain and straw yields. The fresh weight of grain was recorded just after threshing and cleaning and adjusted to $14 \%$ moisture content.Weed index (WI) was calculated by the following formula as suggested by Gill and Vijay(1969).

Weed index $(\%)=\frac{x-y}{x} \times 100$

Where, $x=$ Total yield from hand weeded, weed free or minimum weed competition plot $y=$ Total yield from treated plots

Since weed population and dry weight have shown high degree of variation, the data were subjected to square-root $\left[(x+0.5)^{0.5}\right]$ transformation to make analysis of variance more valid as suggested by Chandel (1984). Data were analyzed with STAR 2.0.1 software for analysis of variance. The mean differencesamong the treatment means were adjudgedby least significant difference (LSD) (Gomez and Gomez, 1984). Correlation was done by the same software.

\section{Results and Discussion}

Weed composition and relative proportions of different weed types in control plots

Weed flora in transplanted Aman rice field was very much diverse. Fourteen weed species infested the control plots which belong to 8 families (Poaceae, Cyperaceae, Pontederiaceae, Alismataceae, Compositae, Sphenocleaceae, Lythraceae and Onagraceae (Table 2). Among the infesting weed species, three were grasses, five were sedges and the rest six were broad-leaved. The weed species belonging to grass family were Cynodon dactylon, Echinochloa colonum and Paspalum distichum, sedges were Fimbristylis miliacea, Scirpus mucronatus, Scirpus supinus, Scirpus acutus and Cyperus difformis, broad-leaved weeds were Monochoria vaginalis, Sagittaria guyanensis, Eclipta prostrata, Sphenoclea zeylanica and Ammannia baccifera and Jussiaea decurrens (Table 2). Similar weed species in transplanted rice during Kharif season were also reported by Prakash et al. (2013).The relative proportion of different weed species into total weed number is presented in Figure 1 . The most prominent weed in the control plots was Cyperus difformis with $27.82 \%$ relative weed density (RWD). The second most important was Scirpus supinus with $14.29 \%$ RWD. Among the grasses, Echinochloa colonum was the highest inrespect of RWD (7.14\%) followed by Cynodon dactylon (5.26\%) and Paspalum distichum (3.38\%).Among the sedges, Cyperus difformis had the maximum RWD (27.82\%) and Scirpus mucronatus had the lowest (1.50\%). Among the broad-leaved weeds, Jussiaea decurrens was the highest with $9.40 \%$ RWD and 
Table 2. Weed composition in control plot of the experimental field of transplanted Aman rice

\begin{tabular}{|c|c|c|c|c|c|}
\hline $\begin{array}{l}\text { Local } \\
\text { name }\end{array}$ & $\begin{array}{l}\text { Common } \\
\text { name }\end{array}$ & Scientific name & $\begin{array}{l}\text { Density } \\
\left(\text { no. } \mathrm{m}^{-2}\right)\end{array}$ & Type & Family \\
\hline Durba & $\begin{array}{l}\text { Bermuda } \\
\text { grass }\end{array}$ & Cynodon dactylon & 18.67 & Grass & Poaceae \\
\hline $\begin{array}{l}\text { Khudey } \\
\text { shama }\end{array}$ & Jungle rice & $\begin{array}{c}\text { Echinochloa } \\
\text { colonum }\end{array}$ & 25.33 & Grass & Poaceae \\
\hline Gitla & Joint grass & Paspalum distichum & 12.00 & Grass & Poaceae \\
\hline Joina & $\begin{array}{l}\text { Hoorah } \\
\text { grass }\end{array}$ & Fimbristylis miliacea & 41.33 & Sedge & Cyperaceae \\
\hline Chechra & Bog bulrush & Scirpus mucronatus & 5.33 & Sedge & Cyperaceae \\
\hline $\begin{array}{l}\text { Khudey } \\
\text { chechra }\end{array}$ & $\begin{array}{l}\text { Dwarf club } \\
\text { rush }\end{array}$ & Scirpus supinus & 50.67 & Sedge & Cyperaceae \\
\hline $\begin{array}{l}\text { Sakta } \\
\text { chechra }\end{array}$ & $\begin{array}{l}\text { Hard stem } \\
\text { bulrush }\end{array}$ & Scirpus acutus & 13.33 & Sedge & Cyperaceae \\
\hline $\begin{array}{l}\text { Green } \\
\text { nakfuli }\end{array}$ & $\begin{array}{c}\text { Small flower } \\
\text { umbrella }\end{array}$ & Cyperus difformis & 98.67 & Sedge & Cyperaceae \\
\hline $\begin{array}{l}\text { Chota } \\
\text { panikachu }\end{array}$ & $\begin{array}{l}\text { Oval leaf } \\
\text { pondweed }\end{array}$ & $\begin{array}{c}\text { Monochoria } \\
\text { vaginalis }\end{array}$ & 8.00 & $\begin{array}{l}\text { Broad- } \\
\text { leaf }\end{array}$ & Pontederiaceae \\
\hline Chand mala & Arrow head & $\begin{array}{l}\text { Sagittaria } \\
\text { guyanensis }\end{array}$ & 2.67 & $\begin{array}{l}\text { Broad- } \\
\text { leaf }\end{array}$ & Alismataceae \\
\hline Keshuti & $\begin{array}{l}\text { White } \\
\text { eclipta }\end{array}$ & Eclipta prostrata & 22.67 & $\begin{array}{l}\text { Broad- } \\
\text { leaf }\end{array}$ & Compositae \\
\hline Zhil marich & Goose weed & $\begin{array}{c}\text { Sphenoclea } \\
\text { zeylanica }\end{array}$ & 8.00 & $\begin{array}{l}\text { Broad- } \\
\text { leaf }\end{array}$ & $\begin{array}{c}\text { Sphenocleacea } \\
\text { e }\end{array}$ \\
\hline Datmari & Tooth cup & Ammannia baccifera & 14.67 & $\begin{array}{l}\text { Broad- } \\
\text { leaf }\end{array}$ & Lythraceae \\
\hline Panilong & $\begin{array}{l}\text { Winged } \\
\text { water } \\
\text { primrose }\end{array}$ & Jussiaea decurrens & 33.33 & $\begin{array}{l}\text { Broad- } \\
\text { leaf }\end{array}$ & Onagraceae \\
\hline Total & & & 354.67 & - & \\
\hline
\end{tabular}




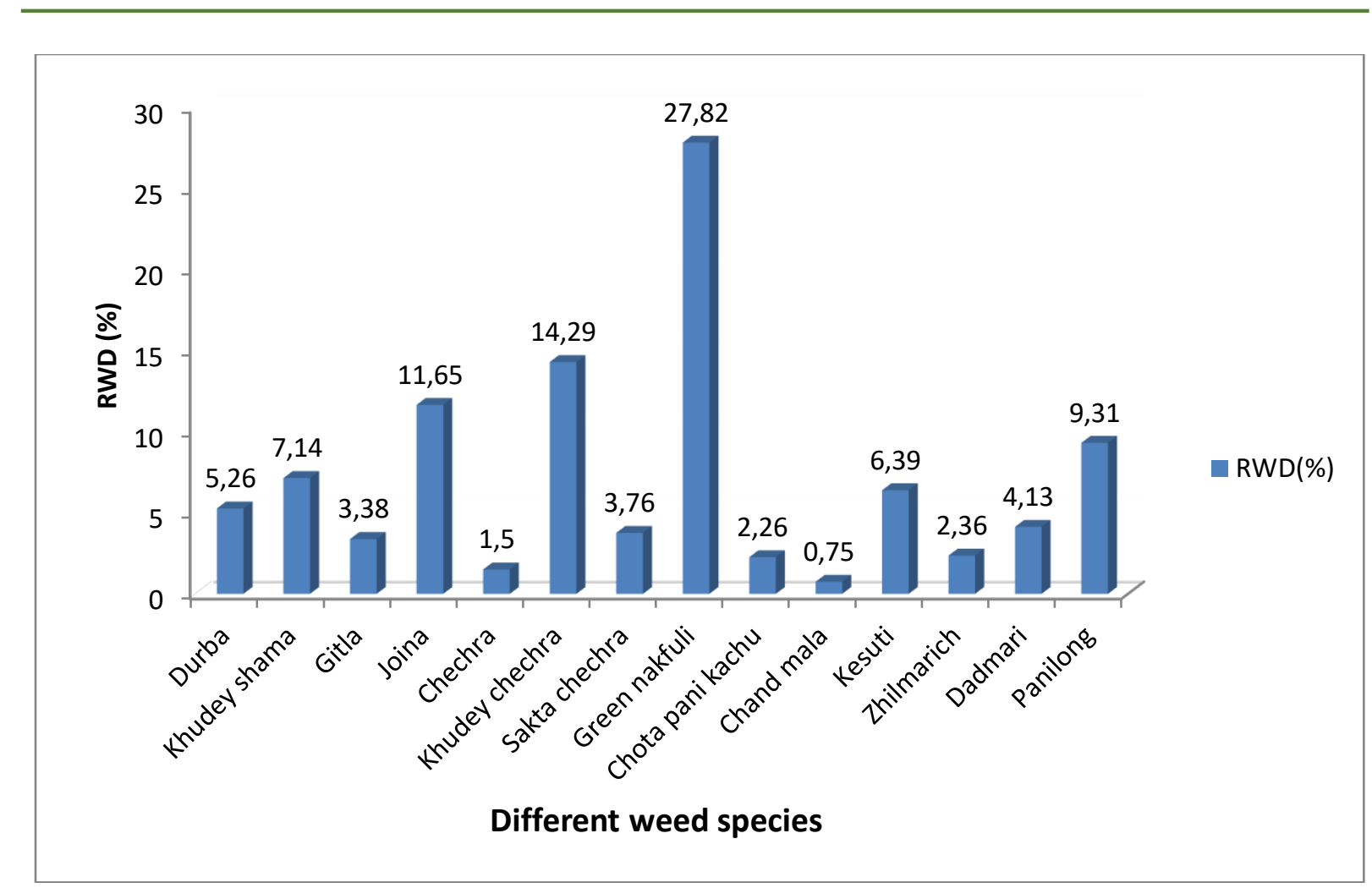

\section{Figure 1. Relative density of different weed species (RWD) in unweeded plot of transplanted Aman rice (var. BRRI dhan49)}

Sagittaria guyanensis was the lowest with 0.75\% RWD. Based on the relative weed density, the most dominant weed species could be arranged in the order of Cyperus difformis $>$ Scirpus supinus $>$ Fimbristylis miliacea $>$ Jussiaea decurrens $>$ Echinochloa colonum $>$ Eclipta prostrata $>$ Cynodon dactylon.The degree of occurrence of different weeds include $15.78 \%$ grasses, $59.02 \%$ sedges and $25.20 \%$ broad leaf in weedy check (Figure 2 ). Therefore, sedges were the dominant weed species in respect of weed density in weedy check. Puniya et al. (2009) also reported sedges as predominant weed flora in transplanted rice.

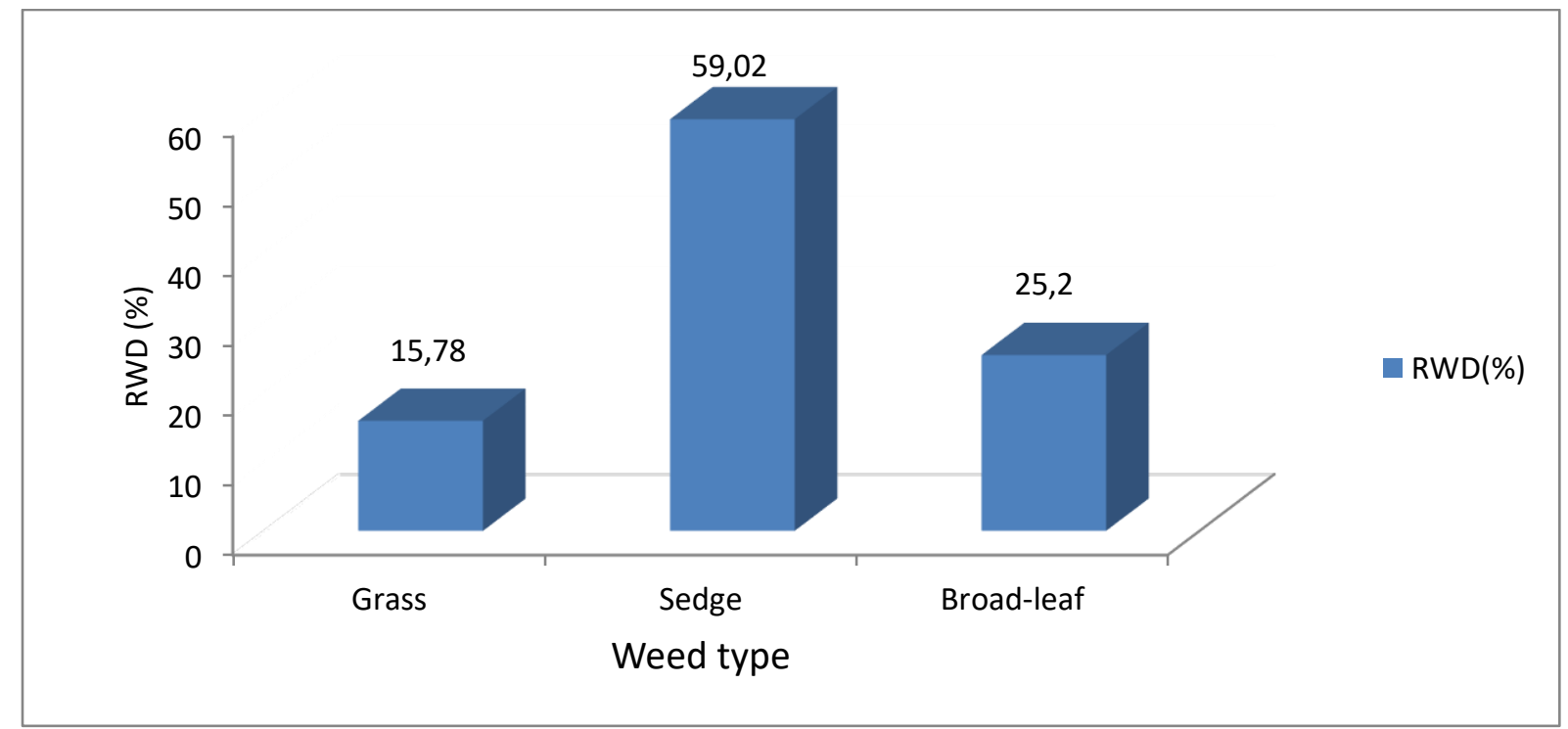

Figure 2. Relative density of different weed (RWD) types in unweeded plot of transplanted Aman rice (var. BRRI dhan49) 


\section{Effect of weed control methods on weed growth}

Species-wise results are presented for the first 5 weeds only as they were dominant in the samples. The data pertaining to the density of individual weed (first five) are presented in Table 3.

\section{Weed density}

\section{Echinochloa colonum (Khudey shama)}

Echinochloa colonum was significantly averted by the weed control treatments (Table $3)$. The non-treated weedy check had the highest weed density ( 25.33 plants $\mathrm{m}^{-2}$ ). Hand weeding and sunflower residues $+100 \%$ Pyrazosulfuron ethyl showed the best performance in controlling this weed. $100 \%$ of this weed plants was controlled by these two treatments. Pendimethalin, butachlor and bensulfuron methyl + acetachlor provided satisfactory weed control, next to these treatments. The results are in agreement with Raj et al.(2016) who demonstrated that hand weeding was the best in reducing Echinochloa colonum while preemergence application of pendimethalin, butachlor and bispyriback sodium significantly reduced the mean density of Echinochloa colonum over weedy check . Incorporation of sunflower residue into field significantly reduced the weed population by $84.21 \%$ over control. However, combination of sunflower residue and pyrazosulfuron ethyl at 75 and $50 \%$ of recommended dose significantly reduced weed density by 89.46 and $85.51 \%$ over control and both the treatments were statistically similar to recommended dose of pyrazosulfuron ethyl. Rawat et al. (2017) observed that sunflower-oat rotation over a 5-year period significantly lowered the density of grassy weeds in fields than in control plots which might be due to allelopathic effect of sunflower.

\section{Fimbristylis miliacea (Joina)}

The density of this weed was significantly influenced by the treatments (Table 3). Weedy check treatment had the highest density $\left(41.33\right.$ plants $\left.\mathrm{m}^{-2}\right)$ of this weed. Pretilachlor, butachlor, bensulfuron methyl + acetachlor, bispyriback sodium, 2,4-D amine, MCPA and sunflower residues $+100 \%$ pyrazosulfuron ethyl provided excellent control and reduced Fimbristylis miliaceaby $100 \%$. Saha and Rao (2010) stated that sulfonyl urea herbicide like bensulfuron methyl, pyrazosulfuron ethyl effectively controlled sedges. Singh et al. (2016) reported that Cyperus spp. could be effectively controlled by butachlor. Integration of sunflower residue with $50 \%$ pyrazosulfuron ethyl reduced weed density by $93.54 \%$ over weedy check and this was statistically similar to recommended dose of pyrazosulfuron ethyl. Sunflower residue $+75 \%$ pyrazosulfuron ethyl resulted in $96.78 \%$ weed control and it was better even than the recommended dose of pyrazosulfuron ethyl.

\section{Scirpus supinus (Khudey Chechra)}

Different weed control treatments significantly influenced the density of this weed (Table 3). The maximum weed density ( 50.67 plants $\mathrm{m}^{-2}$ ) was found in the non-treated weedy plot. No weed of this species was observed in pendimethalin, pretilachlor, butachlor and bensulfuron methyl + acetachlor treated plots which indicate excellent control of Scirpus supinus. Singh et al. (2016) stated that Cyperus spp. was efficiently controlled by butachlor. Recommended dose of pyrazosulfuron ethyl, sunflower residue alone, sunflower residue + $100 \%$ pyrazosulfuronethyl, sunflower residue $+75 \%$ pyrazosulfuron ethyl and sunflower residue $+50 \%$ pyrazosulfuron ethyl were statistically similar with respect to weed control. However, incorporation of sunflower residue alone reduced $64.48 \%$ of this weed species over 
weedy check. Sunflower residue coupled with $100 \%, 75 \%$ and $50 \%$ pyrazosulfuron ethyl resulted in $76.32 \%, 76.32 \%$ and $70.40 \%$ reduction of weed density over weedy check.

\section{Cyperus difformis (Green nakfuli)}

All the weed control treatments significantly reduced the density of Cyperus difformis compared with the weedy check (Table 3). The highest weed density of this weed was observed in weedy check ( 98.67 plants $\mathrm{m}^{-2}$ ). Butachlor and bensulfuron methyl + acetachlor controlled all plants of this weed which was similar to weed free treatment. Singh et al. (2016) also observed that Cyperus spp. was efficiently controlled by butachlor. Reddy et al. (2000) reported that ethoxysulfuron provided a $100 \%$ control of Cyperusdifformis in transplanted rice. However, sunflower residue incorporation alone resulted in $74.32 \%$ control of this weed species which was similar to recommended dose of pyrazosulfuron ethyl, sunflower residue $+75 \%$ pyrazosulfuron ethyl and sunflower residue $+50 \%$ pyrazosulfuron ethyl. Sunflower residue along with $100 \%, 75 \%$ and $50 \%$ pyrazosulfuron ethyl resulted in $82.43 \%, 81.08 \%$ and $77.02 \%$ reduction of weed density over weedy check.

\section{Jussiaea decurrens (Panilong)}

Density of Jussiaea decurrens was significantly affected by different weed control treatments (Table 3). The highest weed density (33.33 plants $\mathrm{m}^{-2}$ ) was recorded in weedy check treatment. $100 \%$ weed of this species was controlled by pendimethalin, pretilachlor, butachlor, bensulfuron methyl + acetachlor, 2, 4-D amine, MCPA and sunflower residues + $100 \%$ pyrazosulfuron ethyl and these were statistically similar to weed free treatment. Akbar et al. (2011) reported that butachlor, pendimethalin and pretilachlor effectively controlled broad-leaved weed like Eclipta alba. Bari (2010) stated that herbicides of phenoxy carboxylic acid group like2,4-D amine and MCPA are broad-leaf killer and they pick broad-leaf weeds. Application of sunflower residue into field significantly reduced the weed population by $96 \%$ over control. However, combination of sunflower residue and pyrazosulfuron ethyl at 75 and $50 \%$ of recommended dose significantly reduced weed density by 84 and $79.99 \%$ over control and these were statistically similar to recommended dose of pyrazosulfuron ethyl. Rawat et al. (2017) also observed that sunflower-oat rotation over a 5-year period significantly lowered the density of broad-leaved weeds in fields than in control plots which might be due to allelopathic effect of sunflower.

\section{Others}

Other weeds like Cynodon dactylon, Paspalum distichum, Scirpus mucronatus, Monochoria vaginalis etc. were observed in small number in the experiment. Total densities of these weeds were significantly influenced by the weed control treatments (Table 3). Hand weeding and sunflower residues $+100 \%$ pyrazosulfuron ethyl, being similar in controlling other weeds significantly reduced the mean density of these weeds as compared to other weed control treatments. These treatments reduced the other weed density to the tune of 2.67-4.00 plants $\mathrm{m}^{-2}$ as compared to 105.34 plants $\mathrm{m}^{-2}$ in weedy check. Among the herbicides used alone, butachlor, pyrazosulfuron ethyl and bensulfuron methyl + acetachlor had the lowest number of other weeds. However, combination of sunflower residue and $75 \%$ pyrazosulfuron ethyl provided other weed population suppression statistically similar to that achieved by the label rate of pyrazosulfuron ethyl. Akbar et al. (2011) reported that butachlor, pendimethalin and pretilachlor effectively controlled all types of weeds. 
Table 3. Effect of weed control methods on weed density $\left(\mathrm{m}^{-2}\right)$ at 45 days after transplanting of transplanted Aman rice

\begin{tabular}{|c|c|c|c|c|c|c|c|}
\hline Treatments & $\begin{array}{l}\text { Echinochloa } \\
\text { colonum }\end{array}$ & $\begin{array}{c}\text { Fimbristylis } \\
\text { miliacea }\end{array}$ & Scirpus supinus & $\begin{array}{l}\text { Cyperus } \\
\text { difformis }\end{array}$ & $\begin{array}{l}\text { Jussiaea } \\
\text { decurrens }\end{array}$ & Others & Total density \\
\hline $\mathrm{T}_{1}$ & 5.07 a (25.33) & 6.46 a (41.33) & 7.14 a (50.67) & 9.93 a (98.67) & 5.80 a (33.33) & 10.26 a (105.34) & 18.81 a (354.67) \\
\hline $\mathrm{T}_{2}$ & $0.71 \mathrm{f}(0)$ & 1.34 c (1.33) & $1.76 \mathrm{f}(2.67)$ & $0.71 \mathrm{f}(0)$ & $0.71 \mathrm{~d}(0)$ & 1.77 i (2.67) & 2.67 i (6.67) \\
\hline $\mathrm{T}_{3}$ & 1.29 e $(1.33)$ & 1.76 b (2.67) & $0.71 \mathrm{~g}(0)$ & 4.21 c (17.33) & $0.71 \mathrm{~d}(0)$ & 4.37 e-g (18.67) & $6.34 \mathrm{fg}(40.00)$ \\
\hline $\mathrm{T}_{4}$ & $2.90 \mathrm{c}(8.00)$ & $0.71 \mathrm{~d}(0)$ & $0.71 \mathrm{~g}(0)$ & 2.67 de (6.67) & $0.71 \mathrm{~d}(0)$ & 4.51 ef $(20.00)$ & $5.92 \mathrm{~g}(34.67)$ \\
\hline$T_{5}$ & 1.29 e (1.33) & $0.71 \mathrm{~d}(0)$ & $0.71 \mathrm{~g}(0)$ & $0.71 \mathrm{f}(0)$ & $0.71 \mathrm{~d}(0)$ & 3.75 h (13.67) & 3.90 h (15.00) \\
\hline $\mathrm{T}_{6}$ & $2.11 \mathrm{~d}(4.00)$ & 1.76 b (2.67) & 3.53 e $(12.00)$ & $4.51 \mathrm{bc}(20.00)$ & 2.67 b (6.67) & $3.93 \mathrm{f}-\mathrm{h}(15.00)$ & 7.80 de (60.34) \\
\hline $\mathrm{T}_{7}$ & 1.29 e $(1.33)$ & $0.71 \mathrm{~d}(0)$ & $0.71 \mathrm{~g}(0)$ & $0.71 \mathrm{f}(0)$ & $0.71 \mathrm{~d}(0)$ & 3.79 gh $(14.00)$ & 3.95 h (15.33) \\
\hline $\mathrm{T}_{8}$ & $2.11 \mathrm{~d}(4.00)$ & $0.71 \mathrm{~d}(0)$ & 1.74 f (2.67) & $3.13 d(9.33)$ & 2.42 b (5.33) & 5.57 c (30.67) & 7.24 ef $(52.00)$ \\
\hline $\mathrm{T}_{9}$ & $4.18 \mathrm{~b}(17.00)$ & $0.71 \mathrm{~d}(0)$ & 6.22 b (38.67) & $2.90 \mathrm{~d}(8.00)$ & $0.71 \mathrm{~d}(0)$ & $4.88 \mathrm{de}(23.33)$ & 9.35 bc (87.00) \\
\hline $\mathrm{T}_{10}$ & $4.49 \mathrm{~b}(19.67)$ & $0.71 \mathrm{~d}(0)$ & 4.67 c (21.33) & 2.10 e $(4.00)$ & $0.71 d(0)$ & $5.10 \mathrm{~cd}(25.67)$ & $8.40 \mathrm{~cd}(70.67)$ \\
\hline $\mathrm{T}_{11}$ & $2.11 \mathrm{~d}(4.00)$ & 1.77 b (2.67) & $4.30 \mathrm{~cd}(18.00)$ & $5.06 \mathrm{~b}(25.33)$ & 1.29 c (1.33) & 6.62 b (43.33) & 9.75 b (94.66) \\
\hline $\mathrm{T}_{12}$ & $0.71 \mathrm{f}(0)$ & $0.71 \mathrm{~d}(0)$ & 3.52 e (12.00) & 4.18 c (17.33) & $0.71 \mathrm{~d}(0)$ & 2.12 i (4.00) & $5.80 \mathrm{~g}(33.33)$ \\
\hline $\mathrm{T}_{13}$ & 1.76 de (2.67) & 1.29 c (1.33) & 3.52 e (12.00) & $4.37 \mathrm{bc}(18.67)$ & 2.41 b (5.33) & 3.76 h (13.67) & 7.33 ef (53.67) \\
\hline $\mathrm{T}_{14}$ & $2.04 \mathrm{~d}(3.67)$ & 1.76 b (2.67) & 3.92 de (15.00) & $4.80 \mathrm{bc}(22.67)$ & $2.68 \mathrm{~b}(6.67)$ & 4.79 de $(22.67)$ & $8.58 \mathrm{~cd}(73.35)$ \\
\hline LS & $* *$ & $* *$ & $* *$ & $* *$ & $* *$ & $* *$ & $* *$ \\
\hline LSD (0.05) & 0.5520 & 0.3709 & 0.6518 & 0.7050 & 0.3593 & 0.5927 & 1.0174 \\
\hline CV (\%) & 14.36 & 14.65 & 12.60 & 11.76 & 13.06 & 7.56 & 8.02 \\
\hline
\end{tabular}

$\mathrm{T}_{1}=$ Weedy check, $\mathrm{T}_{2}=$ Weed free check by hand weeding twice, $\mathrm{T}_{3}=$ Pendimethalin, $\mathrm{T}_{4}=$ Pretilachlor, $\mathrm{T}_{5}=$ Butachlor, $\mathrm{T}_{6}=$ Pyrazosulfuron ethyl, $\mathrm{T}_{7}=\mathrm{Bensulfuron}$ methyl + Acetachlor, $\mathrm{T}_{8}=$ Bispyriback sodium, $\mathrm{T}_{9}=2,4-\mathrm{D}$ amine, $\mathrm{T}_{10}=\mathrm{MCPA}, \mathrm{T}_{11}=$ Sunflower residues, $\mathrm{T}_{12}=$ Sunflower residues $+100 \%$ Pyrazosulfuron ethyl, $\mathrm{T}_{13}=$ Sunflower residues $+75 \%$ Pyrazosulfuron ethyl, $\mathrm{T}_{14}=$ Sunflower residues $+50 \%$ Pyrazosulfuron ethyl, $\mathrm{LS}=$ level of significance. Figures in parentheses are original values. The data were subjected to square root $\left[(x+0.5)^{0.5}\right]$ transformation before statistical analysis. Figures in a column followed by different letters differ significantly, but with common letter ( $s$ ) do not differ significantly at $5 \%$ level of probability 


\section{Total density}

All the weed control methods reduced the density of total weeds over weedy check (Table 3). Weedy check registered the highest total mean weed density (354.67 plants $\mathrm{m}^{-2}$ ) while weed free treatment by hand weeding registered the lowest ( 6.67 plants $\mathrm{m}^{-2}$ ). Akbar et al. (2011) stated that hand weeding recorded higher weed suppression than chemical weed control. Butachlor and bensulfuron methyl + acetachlor were statistically similar in controlling total weed density and significantly reduced the total weed density over weedy check and other herbicides tested alone or in combination with sunflower residues. Hasanuzzaman et al. (2008) demonstrated that application of butachlor rendered efficient weed control.Both the herbicides reduced the total mean weed density by about $96 \%$ over weedy check. The post-emergence herbicide viz. 2, 4-D amine and MCPA were the worst in this regard. 2, 4-D amine and MCPA being broad leaf killer, they only picked broad leaved weeds, while the grasses escaped its control. Hence their overall effect was lesser as compared to other herbicides. However, reduced doses of pyrazosulfuron ethyl (75\%) in combination with sunflower residue had greater weed suppression than that realized with recommended dose of pyrazosulfuron ethyl used alone. Sole application of sunflower residue resulted in $73.31 \%$ control of total weed population. Sunflower residue along with $100 \%, 75 \%$ and $50 \%$ pyrazosulfuron ethyl resulted in $90.60 \%, 84.87 \%$ and $79.32 \%$ reduction of total weed density, respectively over weedy check. However, application of $50 \%$ of the recommended dose of pyrazosulfuron ethyl coupled with sunflower residue rendered statistically similar suppression of total weed density to that of recommended dose $(100 \%)$ of the same herbicide used alone.

\section{Total weed dry weight}

The data on weed dry matter recorded from different weed control treatments at 45 DAT are presented in Table 4. All weed control treatments significantly reduced the total weed dry weight compared with non-treated plots. The minimum weed dry weight of weeds was obtained from manual weeding $\left(0.49 \mathrm{~g} \mathrm{~m}^{-2}\right)$ and the maximum weed dry weight was obtained from weedy check $\left(51.81 \mathrm{~g} \mathrm{~m}^{-2}\right)$. Among the sole herbicide treatments, butachlor recorded the lowest weed dry weight $\left(6.43 \mathrm{~g} \mathrm{~m}^{-2}\right)$ and 2, 4-D amine the highest $\left(10.98 \mathrm{~g} \mathrm{~m}^{-2}\right)$. None of the treatments were comparable to manual weeding in reducing total weed dry weight. However, sole application of sunflower residue and sole application of pyrazosulfuron ethyl recorded statistically similar total weed dry weight indicating the allelopathic effect of sunflower. Sunflower residues $+50 \%$ pyrazosulfuron ethyl, sunflower residues $+75 \%$ pyrazosulfuron ethyl, butachlor and bensulfuron methyl + acetachlor were statistically similar and better than all other herbicides. Raj et al. (2016) observed that total weed dry biomass at harvesting of rice was significantly reduced by pre-emergence application of pendimethalin, butachlor and bispyriback sodium over weedy check.Application of butachlor gave the effective weed control as reported by Hasanuzzaman et al. (2008).

\section{Weed control efficiency (WCE)}

Manually weeded plots maintained the highest weed control efficiency (99.05\%) followed by sunflower residues $+100 \%$ pyrazosulfuron ethyl $(93.46 \%)$, while the least was maintained by the post-emergence herbicide 2, 4-D amine (Table 4).Moorthy and Saha (2002) also recorded higher weed control efficiency $(93.10 \%)$ in hand weeding treatments. Herbicide-treated plots rendered higher weed control efficiency than weedy plots.Among the sole herbicide treatments, the pre-emergence herbicide butachlor gave the 
best weed control efficiency (87.59\%), only next to manual weeding. Bari (2010) stated that butachlor provided better weed control efficiency. However, sunflower residues $+75 \%$ pyrazosulfuron ethyl and sunflower residues $+50 \%$ pyrazosulfuron ethyl applications were better than sole application of pyrazosulfuron ethyl at recommended rate in respect of weed control efficiency. Weed control efficiency in sole sunflower residue application was $78.11 \%$ which was close to sole application of pyrazosulfuron ethyl at recommended rate. It indicates that a reduced level of pyrazosulfuron ethyl may be feasible for satisfactory weed control. Nikneshan et al. (2011) alsodemonstrated that extract of sunflower at $100 \%$ concentration suppressed over $80 \%$ of narrow- and broad-leaved weeds in wheat indicating allelopathic properties of sunflower.

Table 4. Effect of weed control methods on weed dry weight, weed control efficiency, grain yield and weed index of transplanted Aman rice

\begin{tabular}{|c|c|c|c|c|c|}
\hline Treatment & $\begin{array}{c}\text { Weed dry } \\
\text { weight } \\
\left(\mathrm{gm}^{-2}\right)\end{array}$ & $\begin{array}{c}\text { Weed } \\
\text { control } \\
\text { efficiency (\%) }\end{array}$ & $\begin{array}{c}\text { Grain yield } \\
\qquad\left(\mathrm{t} \mathrm{ha}^{-1}\right)\end{array}$ & $\begin{array}{c}\% \text { increase } \\
\text { yield over } \\
\text { control }\end{array}$ & $\begin{array}{c}\text { Weed } \\
\text { index } \\
(\%)\end{array}$ \\
\hline $\mathrm{T}_{1}$ & 7.22 a (51.81) & 0.00 & $3.38 \mathrm{~d}$ & - & 34.24 \\
\hline $\mathrm{T}_{2}$ & 0.97 h (0.49) & 99.05 & $5.14 \mathrm{a}$ & 52.07 & 0.00 \\
\hline $\mathrm{T}_{3}$ & $\begin{array}{c}3.05 \mathrm{~b}-\mathrm{d} \\
(8.83)\end{array}$ & 82.96 & $4.71 \mathrm{ab}$ & 39.35 & 8.37 \\
\hline $\mathrm{T}_{4}$ & 2.98 c-e $(8.37)$ & 83.84 & $4.72 \mathrm{ab}$ & 39.64 & 8.17 \\
\hline $\mathrm{T}_{5}$ & 2.63 ef (6.43) & 87.59 & $4.81 \mathrm{ab}$ & 42.31 & 6.42 \\
\hline $\mathrm{T}_{6}$ & 3.22 bc (9.91) & 79.29 & $4.41 \mathrm{bc}$ & 30.47 & 14.20 \\
\hline $\mathrm{T}_{7}$ & $2.68 \mathrm{~d}-\mathrm{f} \quad(6.78)$ & 83.77 & $4.73 \mathrm{ab}$ & 39.94 & 7.98 \\
\hline $\mathrm{T}_{8}$ & 3.20 bc (9.80) & 81.08 & $4.51 b c$ & 33.43 & 12.26 \\
\hline $\mathrm{T}_{9}$ & 3.39 b (10.98) & 77.67 & $4.01 \mathrm{c}$ & 18.64 & 21.98 \\
\hline $\mathrm{T}_{10}$ & $3.26 \mathrm{bc}(10.15)$ & 80.41 & $4.11 \mathrm{c}$ & 21.60 & 20.04 \\
\hline $\mathrm{T}_{11}$ & 3.44 b (11.34) & 78.11 & $4.40 \mathrm{bc}$ & 30.18 & 14.40 \\
\hline $\mathrm{T}_{12}$ & $1.97 \mathrm{~g}(3.39)$ & 93.46 & $4.97 \mathrm{ab}$ & 47.04 & 3.31 \\
\hline $\mathrm{T}_{13}$ & $2.58 \mathrm{f} \quad(6.14)$ & 88.14 & $4.46 \mathrm{bc}$ & 31.95 & 13.23 \\
\hline $\mathrm{T}_{14}$ & $2.94 c-f(8.16)$ & 84.25 & $4.45 \mathrm{bc}$ & 31.66 & 13.42 \\
\hline LS & $* *$ & - & $* *$ & - & - \\
\hline LSD (0.05) & 0.3952 & - & 0.58 & - & - \\
\hline CV (\%) & 7.57 & - & 7.74 & - & - \\
\hline
\end{tabular}

$T_{1}=$ Weedy check, $T_{2}=$ Weed free check by hand weeding twice, $T_{3}=$ Pendimethalin, $T_{4}=$ Pretilachlor, $T_{5}=$ Butachlor, $\mathrm{T}_{6}=$ Pyrazosulfuron ethyl, $\mathrm{T}_{7}=$ Bensulfuron methyl + Acetachlor, $\mathrm{T}_{8}=$ Bispyriback sodium, $\mathrm{T}_{9}=2,4-\mathrm{D}$ amine), $\mathrm{T}_{10}=\mathrm{MCPA}, \mathrm{T}_{11}=$ Sunflower residues, $\mathrm{T}_{12}=$ Sunflower residues $+100 \%$ Pyrazosulfuron ethyl, $\mathrm{T}_{13}=$ Sunflower residues $+75 \%$ Pyrazosulfuron ethyl, $\mathrm{T}_{14}=$ Sunflower residues $+50 \%$ Pyrazosulfuron ethyl, $L S=$ level of significance.Figures in a column followed by different letters differ significantly, but with common letter ( $s$ ) do not differ significantly at $5 \%$ level of probability.

\section{Effect of weed control methods on grain yield and weed index Grain yield}

Weed control treatments had significant effect on grain yield of T. Aman rice (Table 4). The weed free plots by hand weeding registered the highest grain yield ( $\left.5.14 \mathrm{t} \mathrm{ha}^{-1}\right)$ and was comparable to pendimethalin, pretilachlor, butachlor, bensulfuron methyl + acetachlor and sunflower residues $+100 \%$ pyrazosulfuron ethyl. Singh et al. (2008) observed that 
different herbicide treatments gave similar yield to that of weed free plots. The weedy check treatment gave significantly the lowest grain yield $\left(3.38 \mathrm{t} \mathrm{ha}^{-1}\right)$. The minimum yield in unweeded control was due to severe weed competition by the uncontrolled weed growth. Among different herbicides, butachlor produced the maximum yield $\left(4.81 \mathrm{t} \mathrm{ha}^{-1}\right)$. Bhanu Rekha et al. (2004) observed that pre-emergence application of butachlor recorded the highest grain yield (4.73 t ha-1) among different herbicides. 2, 4-D amine and MCPA recorded the lowest grain yields (4.01 and $4.11 \mathrm{t} \mathrm{ha}^{-1}$, respectively). The pre-emergence herbicides (sole) treated plotsincreased the grain yield ranging from $30.47 \%$ to $42.31 \%$ with an average value of $37.52 \%$ over weedy check, while the respective increase in yields under 2, 4-D amine and MCPA were only $18.64 \%$ and $21.60 \%$, respectively. The present result confirms the findings of Bari (2010) who reported higher grain yield of rice with pre-emergence herbicide like butachlor than with post-emergence herbicide like MCPA. It might be due to the fact that pre-emergence herbicides offered early season weed control up to the period of full canopy cover by rice plants, which might have contributed to higher grain yield. Application of post-emergence herbicides at 25 DAT could not bring the desired benefits as weeds grew luxuriantly and competed with the crop for nutrients, light, water and space. Moreover, they effectively controlled only broad leaved weed as shown in Table 3. It is noticeable here that grain yields produced by sunflower residue alone and sunflower residue + pyrazosulfuron ethyl at 75 and $50 \%$ of recommended dose were comparable to pyrazosulfuron ethyl used alone. In seems that a reduced rate of pyrazosulfuron ethyl may be feasible for providing satisfactory grain yield when it is applied simultaneously with sunflower residue. These results are in agreement with the findings of Alsaadawi and Sarbout (2015) who observed that combination of lower rate of trifluralin and sunflower residues at $6 \mathrm{t} \mathrm{ha}^{-1}$ significantly reduced weed density and weed biomass by 79 and $90 \%$,respectively over control.

\section{Weed index}

Weed index is an ideal parameter to judge the effectiveness of weed control treatments. This is a measure of reduction in the grain yield due to competition stress offered by weeds asagainst weed free treatment. The lower weed index indicates higher effectiveness of a weed control treatments. The crop yield is inversely related to weed index. All the weed control methods showed lower weed index (3.31-21.98\%) than the weedy check $(34.24 \%)$ (Table 4). Singh et al. (2008) reported that the application of different herbicide treatments recorded lower weed index. The highest weed index in weedy check was due to lowest grain yield associated with uncontrolled weed growth throughout the crop growth period. Preemergence herbicides exhibited lower weed index as compared to post-emergence herbicides. However, the lowest weed index was noticed in sunflower residues along with $100 \%$ pyrazosulfuron ethyl (3.31\%) application followed by butachlor $(6.42 \%)$ due to satisfactory weed control. The effective control of weeds by these treatments might have enabled the crop to utilize available resources like light, nutrients, moisture and space to a greater extent resulting in higher yield.

\section{Correlation between pairs of characters}

The data pertaining to correlation co-efficient values $(r)$ worked out for grain yield versus total weed density, total weed dry weight and weed control efficiency are presented in Table 5. Grain yield showed significant positive correlation with weed control efficiency $\left(0.843^{*}\right)$. Grain yield had significant negative correlation with total weed density $(-0.929 * *)$ and total weed dry weight $\left(-0.902^{* *}\right)$. Mondal et al. (2018) also reported a strong negative 
correlation of weed density and weed dry matter with grain yield. Weed control efficiency was negatively correlated with weed density $\left(-0.915^{* *}\right)$ and weed dry weight $\left(-0.967^{* *}\right)$.

Table 5. Correlation co-efficient ( $r$ ) values between pairs of characters

\begin{tabular}{|c|c|c|c|c|}
\hline Correlation & Grain yield & Weed density & Weed dry weight & $\begin{array}{l}\text { Weed control } \\
\text { efficiency }\end{array}$ \\
\hline Grain yield & 1.000 & & & \\
\hline Weed density & $-0.929 * *$ & 1.000 & & \\
\hline $\begin{array}{l}\text { Weed dry } \\
\text { weight }\end{array}$ & $-0.902 * *$ & $0.937 * *$ & 1.000 & \\
\hline $\begin{array}{l}\text { Weed control } \\
\text { efficiency }\end{array}$ & $0.843^{* *}$ & $-0.915^{* *}$ & $-0.967^{* *}$ & 1.000 \\
\hline
\end{tabular}

\section{Conclusions}

The results of the study showed that among different herbicides, butachlor produced the highest grain yield of T. Aman rice comparable to hand weeding. Thus, the use of butachlor may be an alternative in controlling weeds more easily and cheaply when there is a labour crisis. Application of sunflower residues in combination with the lower rate (75 or $50 \%$ ) of pyrazosulfuron ethyl may be considered as an eco-friendly approach in sustainable agriculture.Further research may be carried out to investigate possible complementary interaction of allelopathic crop residues with other herbicides against weeds in field crops for further improvement of the efficacy of this technique.

\section{References}

Akbar, N., Ullah, E. and Jabran, K. M.A. 2011. Weed management improves yield and quality of direct seeded rice. Asian J. Crop Sc. 5(6): 688-694.

Alsaadawi, I. S., Khaliq, A., Al-Temimi, A. A. and Matloob, A. 2011. Integration of sunflower residues with a pre-plant herbicide enhances weed suppression in broad bean. Planta DaninhaVicosa-MG. 29 (4): 849-859.

Alsaadawi, I.S. and Sarbout, A. K. 2015. Reducing herbicide rate in combination with allelopathic sunflower residues for weed control in cowpea. J. Allelochemical Interact. 2 (1): 9-16.

Bari, M. N. 2010. Effects of herbicides on weed suppression and rice yield in transplanted wetland rice. Pakistan J. Weed Sci. Res. 16(4): 349-361.

Bhanu Rekha, K., Kavitha, P., Shrinivasa Raju, M. 2004. Performance of herbicides for weed control in transplanted rice (Oryza sativa L.). The Andhra Agric. J. 51 (1 \& 2): 1-4.

Bhuiyan, M. K. A. 2016. Effect of resource conservation technologies and weed management on nitrogen use efficiency, growth and yield of rice. PhD thesis, Bangldesh Agricultural University, Mymensingh.

Bhuiyan, M. K. A., Mahbub, M. M., Baki, Z. I, Nahar, L. 2017. Sensitivity of Annual Weeds against Sulfentrazone 48 SC herbicide in Rice Cultivation. Bangladesh Rice J. 21 (1): 6170.

Chandel, S. R.S. 1984. A Hand Book of Agricultural Statistics, 7th Ed., pp. 358-359. 
Gill, G. S. and Vijay, K. K. 1969. Weed index, new method of reporting weed control trials. Indian J. Agron. 14: 96-98.

Gomez, K. A. and Gomez, A. A. 1984. Statistical Procedure for Agriculture Research. 2nd Edition. John Willey and Sons, New York. p.680.

Hasanuzzaman, M., Obaidulislam, M. and Shafiuddinbapari, M. 2008. Efficacy of different herbicides over manual weeding in controlling weeds in transplanted rice. Australian J. Crop Sci.2 (1): 18- 24.

Khanh, T.D., Chung, M.I., Xuan, T.D. and Twta, S. 2005. The exploitation of crop allelopathy in sustainable agriculture. J. Agron. Crop Sci. 19: 1 172-184.

Mani, V.S., Pandita, M.I., Gautam, K. C. and Das, B. 1973. Weed killing chemicals in potato cultivation. Indian Farm. 23: 7-13.

Mondal, B., Ghosh, A., Bandopadhyay, P. and Ghosh, R. 2018. Influence of herbicide mixture on composite weed flora and yield of transplanted rice under system of rice intensification. J. Hill Agric.9(1): 49-54.

Moorthy, B.T.S. and Saha, S. 2002. Bio-efficacy of certain new herbicide formulations in puddle-seeded rice, CRRI, Cuttack. Indian J. Weed Sci. 34: 46-49.

Nikneshan,P., Karimmojeni, H., Moghanibashi, M., and Hosseini, N. A. S. 2011. Allelopathic potential of sunflower on weed management in safflower and wheat Asian J. Crop Sci. 5 (11): 1434-1440.

Prakash, C., Shivran, R. K.and Koli, N. R. 2013. Bioefficacy of new herbicides in transplanted rice. Indian J. Weed Sci. 45 (4): 282-284.

Puniya, R., Pandey, P.C. and Bisht, P.S. 2009. Evaluation of new herbicides in transplanted rice (Oryza sativa L.). Pantnagar J. Res. 7 (1): 115-119.

Raj, R., Kumar, A., Kumar, V., Singh, C.B.and Pandey, U.C. 2016. Herbicide options for controlling weeds in transplanted rice (Oryza sativa) under North Eastern Plains Zone Indian J. Agron. 61 (2): 197-203.

Rawat, L.S., Maikhuri, R.K., Bahuguna,Y.M., Jha, N.K. and Phondani, P.C. 2017. Sunflower allelopathy for weed control in agriculture system J. Crop Sci. Biotech. 20 (1): 45-60.

Reddy, C.N., Reddy, M.D. and Devi, M.P. 2000. Evaluation of fenoxyprop-P-ethyl and ethoxysulfuron in transplanted rice. Indian J. Weed Sci. 32(1/2): 105-107.

Saha, S.and Rao, K.S. 2009. Efficacy of sulfonyl urea herbicides for broad spectrum weed control in wet direct sown summer rice. Oryza. 46 (2): 116-119.

Saif, H.B., Bari, M.N., Islam, M.R. and Rahman, M.A. 2016. Allelopathic potential of sunflower extract on weed control and wheat yield under subtropical conditions. Intl. J. Applied Sc. 2 (40): 44-48.

Singh, S., Ladha, J.K., Gupta, G.K., Bhusan, L. and Rao, A.N. 2008. Weed management in aerobic rice systems under varying establishment methods. Crop Prot. 27: 660-671.

Singh,V.P., Singh, G. and Singh, M. 2005. Effect of Bensulfuron-methyl (Londax 60 DF) on sedges and non-grassy weeds in transplanted rice. Indian J. Weed Sci.,37 (1\&2): 40-44.

Singh,V.P., Joshi, N., Bisht, N., Kumar,A. Satyawali, K.and Singh, R.P. 2016. Impact of various doses of butachlor on weed growth, crop yield of rice, microbial population and residual 
effect on wheat crop. Intl. J. Sci. Environ. 5 (5): 3106 - 3114.

Singh, T., Satapathy, B.S., Goautam, P., Lal, B., Kumar, U., Saikia, K. and Pun, K.B. 2017. Comparative efficacy of herbicides in weed control and enhancement of productivity and profitability of rice. Expl. Agric. 1- 